\title{
NARRATIVAS MEDIEVAIS IBÉRICAS: abordagem semiótica
}

\author{
José D'Assunção Barros ${ }^{1}$
}

\begin{abstract}
Resumo
As possibilidades de tratamento historiográfico de fontes narrativas, com ênfase em metodologias desenvolvidas no campo da Semiótica e da Lingüística, têm merecido a atenção de um setor significativo da historiografia na última década. Neste artigo, são examinadas algumas narrativas medievais da Idade Média portuguesa que aparecem nos livros de linhagens do século XIII com vistas à identificação dos principais traços de um Imaginário Cavaleiresco que foi essencial para a formação da identidade nobiliárquica. Entre outros pontos, são examinadas as intertextualidades presentes neste conjunto de narrativas que integra parte dos livros de linhagens, concomitantemente com as descrições genealógicas. Investiga-se, na segunda parte do ensaio, a influência da ética aristotélica no padrão cavaleiresco que é definido preponderantemente nas narrativas linhagísticas.
\end{abstract}

Palavras-chave: Narrativas medievais; Idade Média Ibérica; genealogias.

\begin{abstract}
The possibilities of historiographic treatment of narratives, with emphasis in methodologies developed in the field of Semiotic and Linguistic, have deserved the interests of a significant section of the Historiography in the last decades. In this article, there will be examined some Portuguese medieval narratives which appears in the Linage Books from the century XIII, in order to identify the principal aspects from a Knight's Imaginary that was essential for the formation of the aristocratic identity. Among other points, they are examined the intertextualities present in the set of narratives that integrate part of the linage books, concomitantly with the genealogical descriptions. They are investigated, in the second part of the essay, the influence of the ethics in the Aristotelian ethics in the knight's pattern that is defined preponderantly in the aristocratic narratives.
\end{abstract}

Key-words: Medieval narratives; Iberian Medieval Age; genealogies.

\footnotetext{
11 Professor adjunto da Universidade Federal Rural do Rio de Janeiro (UFRRJ). Doutor em História pela Universidade Federal Fluminense. No Ensino de História, tem se especializado nas áreas de Metodologia, Teoria e Historiografia, História Cultural e História Política, e tem escrito livros e artigos relacionados a estes campos. Entre suas obras mais recentes destacam-se os livros O Campo da História (Petrópolis: Vozes, 2004), O Projeto de Pesquisa em História (Petrópolis: Vozes, 2005), Cidade e História(Petrópolis: Vozes, 2007) e A Construção Social da Cor (Petrópolis: Vozes, 2007).
} 
A Idade Média Ibérica (Portugal e regiões que constituem a atual Espanha) legou aos historiadores inúmeras fontes narrativas que os habilitam a compreender melhor a sua sociedade, a sua vida cotidiana, as suas relações de poder, a sua cultura, e tantos outros aspectos que hoje nos permitem uma aproximação deste mundo que, de certo modo, compõe uma parte importante das nossas raízes históricas.

Para o período situado entre os séculos XI e XIV, algumas das narrativas com que hoje podem contar os historiadores estão incluídas nas crônicas e nos chamados 'livros de linhagens'. Estes últimos constituíam na verdade "genealogias", gênero literário que convém definir antes de iniciarmos uma reflexão sobre a possibilidade de analisarmos as narrativas nele contidas a partir de métodos semióticos diversos e com vistas à elucidação de aspectos relacionados ao imaginário medieval.

Antes de mais nada, é preciso considerar que as genealogias familiares desempenharam na Idade Média um papel de primeira instância para a reconstrução social da Memória, notadamente no seio da nobreza feudal. Reconstruir uma lista de antepassados, de parentes e contraparentes, de relações entre um homem e os heróis ou traidores familiares que o precederam, era inserir este homem em um sistema de valores ou contravalores. Atrelar o indivíduo nobre a uma linhagem ou a um imbricamento de linhagens era não só lhe dar uma identidade, mas atribuir valores positivos ou negativos a esta identidade. Sob a pretensa iluminação de um ou mais pontos do passado, o indivíduo podia se ver imaginariamente investido de ares de herói ou de traidor, de realeza ou de vilania, de aliado ou de inimigo desta ou daquela família socialmente prestigiada. A lista genealógica, enfim, era como que uma arma afiada, pronta para recortar o espaço social nobiliárquico conforme a conveniência dos seus manipuladores ou conforme os aspectos ideológicos mais amplos.

Nos reinos ibéricos dos séculos XI ao XIV, as genealogias assumiram ainda uma característica própria: deixaram de ser meras listas de casamentos e filiações para constituírem um gênero híbrido que misturava a crônica à genealogia propriamente dita. Assim, nesta espécie de texto, um tipo de 'discurso genealógico' em forma de lista familiar - que vai descrevendo uma cadeia linhagística nos seus sucessivos desdobramentos - vê-se, de momentos em momentos, entrecortado por um tipo de 'discurso narrativo' que é 
interpolado à lista genealógica para pretensamente caracterizar o indivíduo ou a família descrita. É o que ocorre, por exemplo, em cada um dos três 'nobiliários' ou livros de linhagens portugueses que chegaram aos nossos dias ${ }^{2}$, todos eles entremeando nas partes genealógicas trechos narrativos de diversos teores.

Desta maneira, os livros de linhagens medievais ibéricos devem ser compreendidos como grandes listagens da nobreza medieval que vinham de tempos em tempos interrompidas por narrativas de teores diversificados, podendo estas irem desde os relatos de grandes acontecimentos históricos ou histórias lendárias até os mais curiosos relatos sobre a vida cotidiana. Estes últimos tipos de relatos, por exemplo, são muito importantes para os historiadores de hoje, porque permitem identificar toda uma sociedade nas suas relações mais primordiais. São relatos onde não estão escondidos os preconceitos sociais, os poderes e micropoderes familiares, os sonhos e frustrações de indivíduos das mais diversas classes sociais, as limitações e estratégias que envolvem a própria vida no seu dia-a-dia, os pequenos heroísmos e as grandes covardias, os surpreendentes gestos de solidariedade e as inesperadas ações de crueldade. Existe, enfim, um mundo real que pulsa neste tipo de narrativa, e que por vezes é idealizado ou escondido em outros tipos de fontes históricas com as quais os historiadores lidam mais habitualmente.

Muito habitualmente, as narrativas que acabavam por serem inseridas em crônicas ou genealogias (livros de linhagens) beneficiavam-se antes de uma ampla circulação oral através dos trovadores, que além de cantarem e tocarem músicas também eram muito habitualmente narradores de casos e frequentavam os mais diversificados ambientes, da corte à praça pública. Desta forma, também devemos ter em vista que estas narrativas também existiam primordialmente em uma modalidade oral, e que somente num segundo momento passavam a ser inseridas nos livros de linhagens que eram produzidos sob os auspícios dos reis e nobres da medievalidade ibérica.

Em seguida, examinaremos uma destas narrativas à luz de alguns métodos semióticos de análise. A narrativa abaixo, que fala do rapto de uma mulher nobre de

\footnotetext{
${ }^{2}$ Livro Velho, 1286-1290; Livro do Deão, 1337-1340; e Livro de Linhagens do Conde D. Pedro, 1340-1344, com refundições posteriores em 1360-1365 e 1380-1383. Os três livros de linhagens possuem edições publicadas, conforme bibliografia.
} 
Portugal, foi extraída do Livro de Linhagens, uma das mais célebres genealogias portuguesas do século XIII.

"E este Gomez Lourenço nom foi casado, mais filhou por força em Avelãas dona Maria Paez Ribeira, que se vinha de Coimbra, u soterrara el rei dom Sancho de Portugal, que a trazia consigo, e de que havia seus filhos, dom Rodrigo Sanchez e e dom Gil Sanchez e dona Tareija Sanchez e dona Constança Sanchez. E ela viindo assi mui triste com seu doo pera sa terra e pera mui grande algo que ela havia, e como mui honrada que la era, viindo com ela seu irmão dom Martim Paaez Ribeiro, seu irmão, sahio a ela ao caminho o sobredito Gomez Lourenço e filhou-a por força. E foi chagado dom Martim Paaez Ribeiro, seu irmão. E levou-a pera terra de Leon, ca nom ousava ficar na terra, ca ela era mui aparentada, e pelos filhos que havia.

E o dito Martim Paaez, seu irmão, querelou logo a el rei dom Afonso de Portugal, e el rei dom Afonso deu-lhe sas cartas pera el rei dom Fernando de Leom, que quisesse estranhar tam mao feito como este. E quando Martim Paaez chegou a el rei dom Fernando de Leom, fez-lhe querela e deu-lhe as cartas d'el rei Afonso de Portugal, e el rei mandou-o logo emprazar, que veesse logo a ele e que trouxesse consigo dona Maria Paaez Ribeira. E el, como foi emprazado, veo-se logo a el rei, a Castel Rodrigo, per conselho de dona Maria Paaez Ribeira, que lhe dezia que era bem de ir a el rei e poer avença antre el e seu irmão, ca el nom quisera ir se o ela nom conselhara.

E quando foi a el rei a Castel Rodrigo, levou consigo a dita Maria Paaez Ribeira, e tanto que chegarom a el rei, leixou-se cair em terra, e fez-lhe querela de como a Gomez Lourenço rousara, e de como trouvera por força de Portugal pera terra de Leom e de como a trazia na terra d'el rei de Leom forçada e per força. E pedio-lhe a el rei por mercee que lhe alçasse del força e que lhe fizesse del justiça pela força em que ela fezera. E el rei disse a Gomez Lourenço que respondesse ao que dissera dona Maria Paaez Ribeira. E el disse que verdade era o que ela dezia, que a rousara, mais que ela lhe dissera que visse ante el rei e que faria a dom Pero Paaez Ribeiro, seu irmão, que lhe perdoasse, e demais que casaria com ela. E ela disse que esto lhe nom dissera senom pera o trazer ante el rei, pera haver corregido o mal que lhe fizera, ca per outra guisa nom poderia del vingada seer. E el rei mandou-o matar por elo"

(LL 36BN9)

$\mathrm{O}$ argumento fundamental é simples, e pode ser reduzido à sequência básica em cinco proposições narrativas, para empregar neste primeiro momento de aproximação o método de análise de sequências narrativas proposto por Tzvetan Todorov (1994). Dona 
Maria Paes Ribeira é uma mulher honrada, que acabara de ficar 'viúva' (na verdade era ela uma antiga barregã do rei Sancho I de Portugal, recentemente falecido) ${ }^{3}$. É deste 'equilíbrio inicial' que se parte. Em dado momento, ocorre a 'perturbação': Gomes Lourenço a rouba por força, para torná-la sua mulher (linhas 7-10). A ‘crise' se instala: Maria Paes Ribeira foi desonrada com toda a sua família, inclusive o irmão Martim Paes Ribeiro que falhara em sendo o responsável por sua segurança no momento do rapto ${ }^{4}$. Uma 'intervenção' régia, mediando os acontecimentos, irá no final da narrativa estabelecer um 'novo equilíbrio' com a punição do culpado e o saneamento da honra familiar. Esta sequência corresponde à espinha dorsal da narrativa, mas dentro dela imbricam-se e interpolam-se várias outras.

O primeiro fator complicador e enriquecedor do enredo narrativo é o fato de que, ao roubar a fidalga, Gomes Lourenço a leva a força para o reino de Leão, o que o afasta teoricamente da jurisdição do rei de Portugal e ameaça resguardá-lo de qualquer punição que pudesse ser impetrada (linhas 10-13). Analisemos de perto este elemento interpolado.

A fuga para Leão, além de ser um mero ato de covardia que, desde já, cola-se à imagem do nobre recalcitrante ("ca non ousava ficar na terra, ca ela era mui aparentada, e pelos filhos que havia") equivale a uma recusa em ser julgado. A fuga para longe da possibilidade de ser julgado corresponde à não-obediência à convocação régia - notando-se que no presente caso a fuga (ou recusa) interrompe um processo de mediação virtual, que efetivamente não chega a se realizar. Para deixar mais clara a questão, a mediação do caso pelo rei de Portugal seria a sequência necessária do relato, não fosse o estratagema do nobre infrator ao buscar refúgio no reino vizinho. Com isto, ele interrompe por antecipação um processo situado no futuro imaginário da narrativa, alterando o curso dos acontecimentos. Examinado desta maneira, podemos dizer que a fuga para Leão encaminha uma nova sequência narrativa que se interpola, virtualmente, a partir do próprio item 'mediação régia' (proposição narrativa $\mathrm{n}^{\circ} 4$ da sequência principal).

${ }^{3}$ É preciso ressaltar que, na Idade Média ibérica, não existe nenhuma depreciação em ser uma 'barregã do rei’ - isto é, em ser uma das mulheres com as quais o rei relaciona-se extramatrimonialmente, chegando a ter com elas filhos bastardos (estes, por sinal, também não são depreciados). Neste aspecto, o rei destaca-se do resto do corpo social, onde as famílias ilegítimas de um homem comum podem sofrer depreciações diversas. Na narrativa examinada, o cronista faz questão de ressaltar a honra da personagem ("e como muito honrada que ela era", linha 6).

${ }^{4}$ A referência também é explícita: "E foi chagado Martim Paaez Ribeiro, seu irmão" (linhas 8-9). 
Ou seja, embora no plano narrativo a fuga para Leão esteja localizada em um momento anterior ao início do processo de mediação, no plano lógico ela ocorre assim que se inicia este processo, pois é ela que efetivamente o interrompe. Assim, temos uma nova sequência que pode ser resumida como se segue: (1) 'equilíbrio inicial' correspondendo ao processo mediador que deveria se desenrolar normalmente [localização virtual]; (2) 'perturbação' ocasionada pela fuga do nobre infrator para Leão, o que interrompe o processo mediador [linha 9]; (3) ‘crise' ou estagnação do processo mediador, que na prática não pode sequer se iniciar; (4) 'intervenção' de Afonso II, mas na verdade do nobre que lhe pede as cartas para sensibilizar o rei Fernando de Leão a encaminhar o processo mediador que já deveria ter começado [linhas 11-15]; (5) instalação do processo de mediação régia em Leão pelo governante deste reino [linhas 15-16], o que conduz a 'novo equilíbrio' em relação à proposição inicial (processo de mediação em curso).

Antes de passarmos às novas sequências que se apresentam imbricadas na sequência narrativa principal, cabe perceber que, tal como ocorre em inúmeras narrativas presentes nos livros de linhagens da época, aparece a leitura da 'mediação régia' como um instrumento da nobreza. Não foi o rei, por iniciativa própria, quem buscou interceder junto ao rei de Leão para que este fizesse justiça. Foi na verdade um nobre, o irmão da dama raptada, quem solicitou ao rei de Portugal as cartas para a sensibilização do rei de Leão. É este nobre, enfim, quem reativa um processo mediador a princípio tendente à nãoinicialização. Vale dizer, é ainda aqui um nobre quem age, ao menos em um dos extratos possíveis de sentido, de maneira similar ao que vemos em diversas narrativas dos livros de linhagens.

Ocorre que o processo de mediação, agora comandado pelo rei Fernando de Leão, efetivamente se instala. Uma nova sequência interpola-se a partir desse novo momento do processo mediador. Maria Paes Ribeira convence ardilosamente o nobre infrator a comparecer diante do rei de Leão, assegurando que assim poderá ser estabelecida a paz com seu irmão e ser legalizado o matrimônio até então ilegítimo entre ela e o nobre que a roubara por força [linhas 17-19]. Antecipa-se ao raptor, portanto, com relação a qualquer tendência virtual que ele pudesse eventualmente manifestar em recusar a convocação régia. Vamos compreender mais de perto esta sequência, uma vez que ela também envolve 
inversões de tempo e aspectos virtuais. Comparemo-la, inicialmente, com a outra narrativa que atrás abordamos.

Existe nos livros de linhagem uma outra narrativa, ambientada no reinado de Dom Sancho II, e que ficou conhecida como "O Tenreiro". Nesta narrativa também ocorre um processo mediado pelo rei, mas a recusa do nobre infrator em atender às convocações régias acaba simplesmente por interromper o processo de mediação, até que este finalmente continua à revelia do infrator. Mas esta solução, embora fosse a única possível naquela lógica narrativa, traz o inconveniente de o nobre infrator ter ficado relativamente impune, pois jamais compareceu fisicamente para receber o castigo. Apesar disto, já se tem aí uma situação significativa, uma vez que o nobre se vira oficialmente depreciado - o que em última instância era o objetivo da narrativa a que nos referimos.

Imaginemos agora uma situação em que o nobre infrator, na narrativa que estamos analisando neste artigo, simplesmente se recusasse a comparecer aos emprazamentos régios. O julgamento à revelia nada mais faria do que deixá-lo rigorosamente impune, em situação idêntica ao equilíbrio inicial. Afinal, a mera desmoralização pública em nada afetaria um nobre que já assumira desde o início um casamento ilícito onde trazia a mulher contra a sua vontade. Desta forma, uma simples desmoralização nada acrescentaria à desmoralização assumida inicialmente, diante da sociedade, pelo nobre infrator. É assim que a recusa em atender à convocação régia, caso ocorresse, simplesmente inviabilizaria o processo de mediação e justiça régia.

O estratagema de Maria Paes Ribeira, rigorosamente necessário para superar por antecipação uma eventual (e ameaçadora) recusa do raptor em comparecer ao emprazamento $^{5}$, aparece consoante esta leitura como uma etapa lógica posterior a uma intenção virtual do nobre infrator de interromper o processo mediador. Antes mesmo que o nobre possa sequer avaliar uma eventual recusa ao comparecimento diante do rei, a dama já interfere decisivamente em sua decisão. O estratagema de Maria Paes Ribeira corresponde, visto por este prisma, a uma 'intervenção antecipada' em uma situação que, embora não chegando a ocorrer, corresponderia a uma etapa lógica necessária.

${ }^{5} \mathrm{O}$ texto explícita a necessidade do estratagema: “ca el nom quisera ir se ela nom conselhara” (linha 19). 
Assim decifrada, a nova sequência fica como se segue: (1) 'equilíbrio inicial': processo mediador em vias de transcorrer normalmente; (2) 'perturbação': recusa virtual de comparecimento à convocação régia; (3) 'crise': interrupção potencial do processo; (4) 'intervenção': estratagema destinado a convencer o infrator a não efetivar o seu nãocomparecimento; (5) comparecimento e retomada do processo de mediação régia.

A sequência acima encaminhada, embora seja a princípio uma interpolação lateral na sequência principal, é talvez o verdadeiro núcleo do exemplo desenvolvido pela narrativa. O seu especial interesse está em que, logo em seguida, é colocado um problema moral que consiste no fundamento da nova sequência que irá se interpolar no plano narrativo. Valendo-se da 'mentira', uma contravirtude não-cavaleiresca, para reparar um mal não-cavaleiresco (e seguramente bem maior) que é o 'rapto', a heroína coloca o rei diante de uma decisão delicada. Que contravirtude aceitar como o mal menor? Uma resposta fácil, mas que, naturalmente, coloca o problema de uma hierarquia de virtudes e infrações cavaleirescas.

Com este novo elemento introduzido no relato, gera-se uma nova sequência, que poderemos considerar a partir do ponto de vista do infrator enganado: (1) equilíbrio inicial: o nobre beneficia-se do casamento ilegítimo obtido à força, permanecendo inatingível pela justiça régia e pelo justiçamento nobiliárquico; (2) perturbação: Maria Paes Ribeiro o engana deliberadamente, para forçar a solução de pendências decorrentes da sequência anterior (rapto e desonra familiar); (3) crise: Gomes Lourenço, que esperava resolver pacificamente os seus erros pregressos, dá-se conta de que fora enganado, e por isto clama ao rei para que este releve suas infrações anteriores e sancione seu casamento [linhas 2629]. Nesta sequência, é importante destacar, Maria Paes Ribeiro é a infratora, e Gomes Lourenço é a vítima; (4) intervenção: O rei intercede finalmente, mas prefere não sancionar o equilíbrio inicial (liberdade de Gomes Lourenço), favorecendo ao contrário a infratora da sequência em vista das sequências pendentes anteriores. (5) equilíbrio novo: o rapto não é 
legitimado, e o vilão raptor é condenado à morte para que a honra nobiliárquica seja restabelecida ${ }^{6}$.

A última proposição narrativa da sequência supradescrita desemboca, naturalmente, na última proposição da sequência principal. Com a condenação à morte de Gomes Lourenço, a narrativa se resolve e todos os problemas se solucionam: (a) o infrator cavaleiresco é punido; (b) a honra da viúva e de sua família é restaurada; (c) restabelece-se a paz nobiliárquica; (d) o rei consegue levar a bom termo a sua atuação mediadora, o que reforça o princípio da autoridade régia. Adicionalmente, encontra-se resolvido um problema moral em torno da contraposição entre duas infrações - a 'mentira', infração menor, e o 'rapto', infração irreparável no período medieval e que, por isto mesmo, clama por uma solução mais drástica. Os valores e desvios cavaleirescos ganham nesta narrativa um princípio de hierarquização.

Vale perceber que aqui, mais uma vez, a 'mentira' foi integrada a um processo de 'manipulação'. O engodo movido por Maria Paes Ribeira consistira precisamente em persuadir Gomes Lourenço de que ela já estava plenamente conformada com o novo marido (o raptor), e que lhe interessava, tanto quanto a ele, normalizar socialmente a situação e por pazes entre o marido raptor e a sua família. É este processo de ocultamento dos verdadeiros sentimentos e intenções da vítima do rapto que se coloca na base deste processo de manipulação. A 'enganadora' (Maria Paes Ribeira) assume aqui dois papéis simultâneos: por um lado, apresenta-se para o 'enganado' (Gomes Lourenço) pelo que ela não é (uma vítima conformada ou 'não-ressentida'); por outro lado, oculta aquilo que verdadeiramente ela é (uma vítima 'ressentida' em busca de reparação e vingança), o que se dá mediante um processo de camuflagem que será desmascarado no momento oportuno.

\footnotetext{
${ }^{6}$ Segundo Todorov, ao final de uma sequência narrativa tradicional estabelece-se, via de regra, um "novo equilíbrio" que é na verdade uma modificação do "equilíbrio inicial". Para a nossa narrativa, há duas possibilidades de leitura. Caso a decisão do rei fosse favorável ao nobre que, pelo menos nesta sequência, fora lesado - teríamos a situação clássica que corrige o desequilíbrio produzido pela perturbação (a mentira). Mas o rei beneficia a infratora, o que naturalmente teria de ocorrer em função do relato mais amplo - e do ponto de vista desta sequência em particular estabelece-se um equilíbrio radicalmente diferenciado, com a punição da vítima (o raptor, culpado nas outras sequências). Por outro lado, se a ênfase é deslocada para o rapto em si mesmo, a leitura pode ser outra. Partiu-se de uma relação não-legítima (o casamento à força), e chegou-se à não-legitimação (ou confirmação de não-legitimação) desta mesma relação. Portanto, temos aqui um novo equilíbrio que se constitui em uma restauração transformada do equilíbrio inicial.
} 
Esta situação coloca em jogo, adicionalmente, o recurso da 'tentação'. A manipuladora propõe ao manipulado objetos muito positivos: a paz do 'marido raptor' com os seus irmãos lhe trará vantagens que incluem desde a legitimação social até possibilidades patrimoniais - como partilhar das posses territoriais da vítima no reino de Portugal, país que lhe está interditado enquanto durar a alternativa do rapto não legitimado. Todos estes aspectos não aparecem explicitados no texto narrativo, mas o leitor-ouvinte aristocrata, bem inteirado acerca dos códigos legitimadores e dos processos de sucessão patrimonial, facilmente os incorpora à compreensão do texto. É assim que funciona, de maneira eficaz, este processo de manipulação que conduzirá Gomes Lourenço à sua condenação final - apesar de suas tentativas de sensibilizar o rei esclarecendo-o de que fora enganado e persuadindo-o de que suas boas intenções seriam relevantes para inocentá-lo ao final do processo (o que seria impossível, conforme já vimos, para um rei medieval e literariamente construído que se encontra sintonizado com um rigoroso código cavaleiresco que propõe uma repulsa absoluta à prática do rapto não justificado).

Para melhor organizar o material narrativo em relação a esta sequência - que envolve um ressentimento camuflado associado a um projeto de vingança e a uma falsa tentativa de reconciliação - propomos um quadrado semiótico de fácil compreensão:

Neste quadrado, o conjunto $\mathrm{S} 1 \rightarrow-\mathrm{S} 1 \rightarrow \mathrm{S} 2$ corresponde ao percurso da 'manipulação' (entrada no campo do 'ilusório' com o recurso a expedientes de dissimulação e falsidade). Maria Paz Ribeira, embora se sentindo desonrada e 'ressentida' (S1), procura mostrar-se 'não-ressentida' (-S1), e propõe enganosamente uma tentativa de 'conciliação' (S2). Atente-se para o fato de que, no mundo cavaleiresco, todo 'justo ressentimento' (pelo menos em questões desta gravidade) deve corresponder a uma vingança ou reparação honrosa; e por isto este âmbito opõe-se no caso ao âmbito acessado pelo 'não-ressentimento injustificado' (a 'não-ação' em termos de reparação da honra, associada a este resignado 'não-ressentimento', remete a posições anticavaleirescas como a 'covardia' ou a 'sujeição').

$\mathrm{Se}$ o percurso $\mathrm{S} 1 \rightarrow-\mathrm{S} 1 \rightarrow \mathrm{S} 2$ corresponde ao processo de 'manipulação' e engodo, o caminho inverso ( $\mathrm{S} 2 \rightarrow-\mathrm{S} 1 \rightarrow \mathrm{S} 1)$ constitui o processo de desvelamento. Diante do rei, e bem sucedida no estratagema de trazer o raptor perante o rei mediador, Maria Paes 
Ribeira abandona a posição de 'falsa conciliação' (S2). Mostra-se, ao contrário, radicalmente 'não-conciliadora' (-S2), chegando a implorar ao rei que resgate a sua honra e condene o raptor que desonrou a ela e a sua família. Com isto, retorna à posição inicial de 'ressentimento' e de exigência de reparação da honra (S1), da qual efetivamente nunca saíra senão para envolver o vilão raptor no já descrito processo de manipulação. O rei acede ao pedido da dama, uma vez que é sua função corrigir toda injustiça e maldade, e condena à morte o raptor. O ciclo completo constitui, portanto, o processo de vingança e de reparação da honra, amplamente realizado. Corresponde também, no esquema de proposições narrativas à maneira de Todorov, ao processo de restabelecimento do equilíbrio inicial, ligeiramente transformado.

Tomando como centro de gravidade a trajetória da personagem Maria Paes Ribeira , é agora possível compreender de uma maneira mais plena o significado e o papel estruturante de vários dos enunciados presentes no texto, postos em relação a cada uma das já citadas posições fundamentais. O conteúdo narrativo pode ser distribuído, desta forma, no próprio esquema elaborado, unindo com setas as passagens características de cada posição (Quadro 2).

Algumas explicações se fazem necessárias. O "quadrado semiótico", tal como proposto pelos seus criadores (Greimas e Courtés, 1989), busca associar dois termos geradores (S1 e S2) que são colocados em relação de contrariedade ('ressentimento' e ‘conciliação', para dar como exemplo o próprio quadrado semiótico que elaboramos, são rigorosamente incompatíveis). Cada um dos dois termos geradores tem o seu oposto (-S1 e -S2). O sinal que marca as diagonais $(\leftarrow \rightarrow)$ representa precisamente uma relação de contradição ('ressentimento' $\longleftrightarrow$ 'não-ressentimento'; 'conciliação' $\longleftrightarrow$ 'nãoconciliação'). Ocorre que S1 e -S2, bem como S2 e -S1, estão sempre em relação de complementaridade (que é representada pelo sinal $\rightarrow$ ). Assim, em nosso esquema, 'nãoconciliação' e 'ressentimento' se complementam, da mesma forma que 'não-ressentimento' e 'conciliação'. 
"leixou-se cair em terra, e fez-lhe querela de como a Gomez Lourenço rousara, e de como a trouvera por força de Portugal pera terra de Leom e de como a trazia na terra d'el rei de Leom forçada e por força"

"E ela disse que esto lhe nom dissera senom pera $\mathrm{o}$ trazer ante el rei, pera haver corregido o mal que lhe firam"
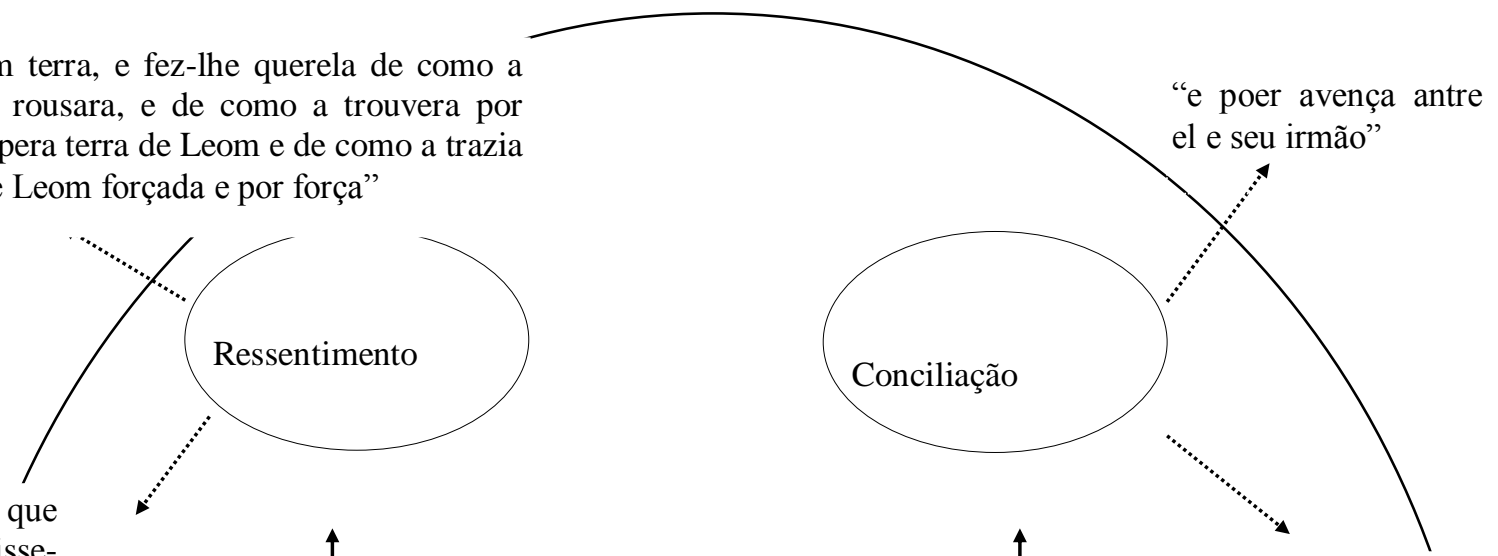

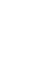
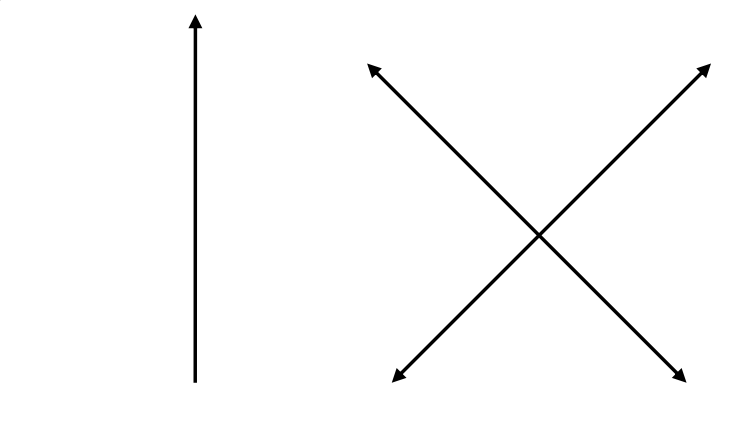

"E pedio-lhe a el rei que verdade era o que ela dezia, que a rousara, mais que ela lhe dissera que viesse ante el rei e que faria a dom Pais Ribeiro, seu irmão, que lhe perdoasse, e demais que casaria com ela"",

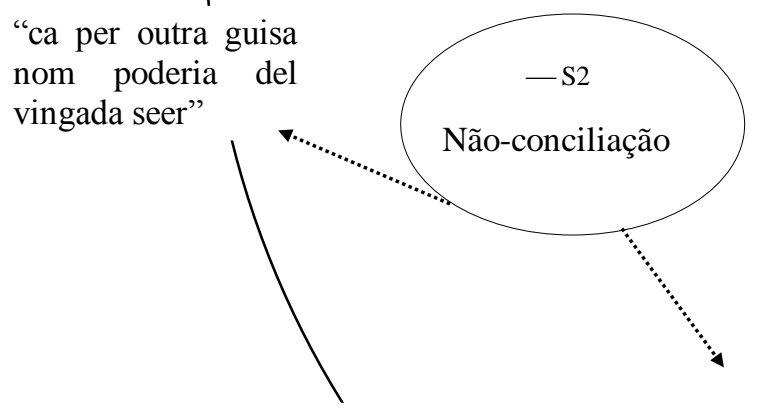

"E pedio-lhe a el rei por mercee que lhe alçasse del força e que lhe fizesse del justiça pela força que em ela fizera"

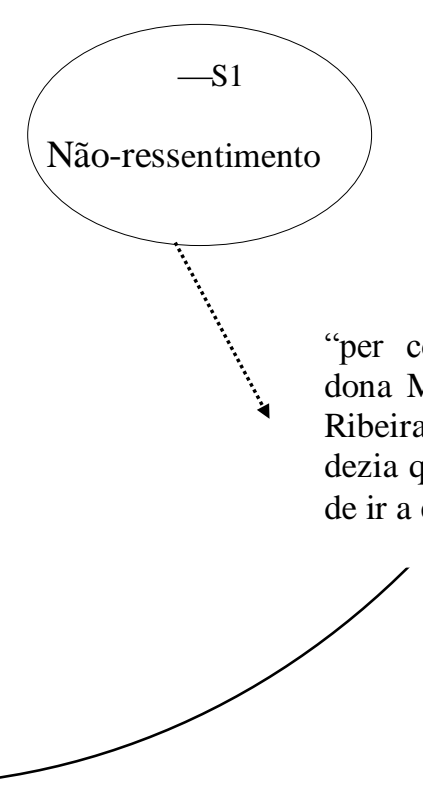

Quadro 2: Quadrado semiótico organizando os conteúdos da sequência 3 da narrativa "A Ribeirinha" (Maria Paz Ribeira envolvendo Gomes Lourenço em um processo de manipulação com vistas à reparação de sua honra) 
O quadrado semiótico, conforme proposto teoricamente por Greimas, tem dois percursos somente: de S1 a S2 passando por -S1, e de S2 a S1 passando por -S2. Foi o que ocorreu na reconstituição semiótica que propusemos para o trecho narrativo analisado, onde a sucessão imediata dos dois percursos correspondeu ao circuito completo da reparação da honra (lembramos que o 'justo ressentimento' da personagem principal equivalia no início do ciclo a um 'projeto de vingança', e no seu final a uma 'realização da vingança').

Alguns 'metatermos', unindo por fora os termos fundamentais de um quadrado semiótico, podem colaborar para a sua compreensão mais plena. Tal procedimento constituiu-se na história de Teoria Semiótica em um aprimoramento posterior do quadrado semiótico - culminando com aquilo que ficou conhecido como "grupos de Klein". Para a nossa sequência em estudo, propomos o seguinte grupo que deverá se superpor ao esquema anterior $^{7}$ :

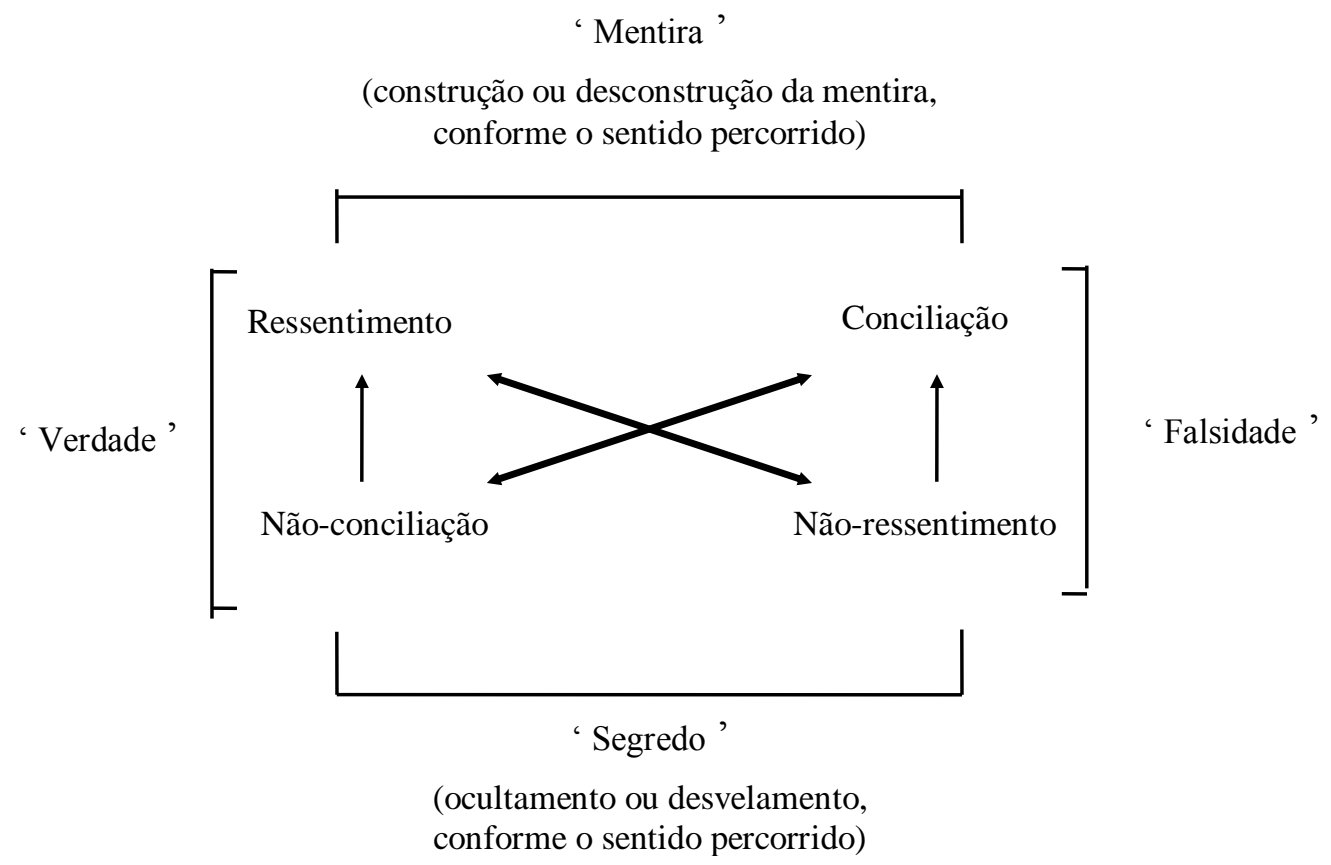

${ }^{7} \mathrm{O}$ 'grupo semiótico' abaixo utilizado não se propõe a ser um 'grupo de Klein' habitual. Corresponde a uma adaptação modificada do 'grupo de Klein' da categoria "veridictória", e foi construído com base na superposição dos metatermos veridictórios ao quadrado semiótico antes elaborado para a narrativa analisada (no 'grupo de Klein veridictório' tradicional, o metatermo 'verdade' aparece como o lado superior do quadrado, no 'grupo' aqui construído, ele é o metatermo lateral esquerdo). 
Procuremos clarificar, antes de mais nada, os metatermos propostos. A combinação 'Ressentimento' e 'conciliação' - dois termos dificilmente conciliáveis senão mediante a adoção de uma relação de dissimulação ou de um projeto de traição futura aparecem unificados pelo metatermo 'mentira'. A junção destes contrários, de fato, só pode ter existência no plano da mentira - particularmente no nosso universo cavaleiresco, onde o 'justo ressentimento' da vítima e da família desonradas exige e corresponde necessariamente a um projeto inicial de 'vingança'.

'Não-conciliação' e 'ressentimento', que já vimos serem complementares, correspondem aos verdadeiros sentimentos da personagem (Maria Paes Ribeira) que encaminha o processo de manipulação com vistas à concretização de uma reparação da honra pessoal e familiar (é dos sentimentos e ações desta personagem, e dos enunciados que os acompanham, que tratamos neste grupo semiótico). O metatermo que une 'nãoconciliação' e 'ressentimento' corresponde, assim, à 'verdade'. Opostamente, 'nãoressentimento' e 'conciliação', embora também compatíveis e complementares, não correspondem aos verdadeiros sentimentos da personagem, mas sim à aparência que ela forja para encaminhar o engodo movido contra o seu opositor. Por isso, este metatermo corresponderá à 'falsidade'.

No lado inferior do quadrado, um novo par incompatível corresponde ao 'segredo' (ser 'não-conciliadora' e não parecer 'ressentida' é a essência deste segredo). Se tomarmos a orientação da 'falsidade' em direção à 'verdade', falaremos aqui de um 'desvelamento' (saída do 'segredo'). Dito de outra forma, a recusa de alguém que se afirma 'nãoressentida' em reconciliar-se leva necessariamente ao desmascaramento de uma situação insustentável. De igual maneira, ao orientarmos o metatermo 'segredo' da verdade para a falsidade temos a entrada no 'segredo'. A junção da 'não-conciliação irredutível' com a ideiade um ‘não-ressentimento' só é possível, de fato, mediante um ocultamento do projeto não-conciliador.

De acordo com a teoria semiótica, os trajetos no 'grupo de Klein' dão-se “pelas beiradas", de "metatermo a metatermo contíguo" (CARDOSO, 1980: 118). No caso proposto, não é possível ir da 'verdade' ao 'falso' sem passar pela 'mentira' (percurso pelo metatermo superior) ou pelo 'segredo' vivido como processo de 'ocultamento' da verdade 
(percurso pelo metatermo inferior). A personagem Maria Paes Ribeira atravessa simultaneamente ambos os percursos, seja enganando o seu raptor com promessas mentirosas, como ocultando os seus verdadeiros sentimentos. Da mesma forma, não é possível retornar da 'falsidade' à 'verdade' sem passar por um 'desmascaramento da mentira' ou por um 'desvelamento do segredo'. Neste último caso, o 'segredo' é vivido de uma nova maneira, agora com uma orientação inversa que corresponde ao processo de revelação. Com isto, podemos ver que certos metatermos modificam-se mediante a sua orientação de leitura (da esquerda para a direita, ou da direita para a esquerda).

Todos os percursos citados são penosos para a personagem representada pela viúva aristocrata (que é cavaleirescamente construída por este tipo de literatura). 'Mentir' pressupõe infringir o código de honra, e deixar-se desmascarar pressupõe uma exposição a uma espécie de vergonha (tanto que a personagem desculpa-se da sua infração em certo ponto da narrativa, justificando-se literalmente ${ }^{8}$ ). Ocultar injustificadamente os verdadeiros sentimentos, enfim, vem carregado no ponto de vista cavaleiresco de uma espécie de covardia. No entanto, para corrigir um mal maior e obter a vingança pretendida, é preciso percorrer este duplo percurso ${ }^{9}$.

É nestes termos que é colocado o problema moral, que naturalmente já se encontra de antemão solucionado, uma vez que o rei cavaleirescamente construído jamais poderia deixar de dar ganho de causa à vítima do rapto. Mas, em todo o caso, a narrativa decifrada neste nível de sentido traz à tona certas tensões decorrentes da necessidade de hierarquizar determinados valores cavaleirescos, de contrapô-los mediante certas contingências, de optar por um em detrimento do outro. Nos entreditos da narrativa repousa a mensagem de que o ideal cavaleiresco, irretocável e plenamente concretizado, só é integralmente realizável, com ausência de contradições, fora do mundo das necessidades.

Um problema como este, cuja concretização faz parte da constituição de um determinado imaginário cavaleiresco que aparece nas narrativas linhagísticas, não se constitui de maneira nenhuma um fenômeno isolado, somente pertinente a esta narrativa.

\footnotetext{
${ }^{8}$ "E ela disse que verdade esto lhe nom dissera senom pera o trazer ante el rei, pera haver corregido o mal que lhe fizera" (linhas 29-30).

9"per outra guisa nom poderia del vingada seer" (linhas 30-31).
} 
Será uma leitura isotópica do nobiliário, e a projeção de quadrados semióticos como este para séries inteiras de narrativas, o que nos permitirá confirmar isto. Por outro lado, não poderemos escapar mais adiante da questão envolvida pelas relações que se estabelecem entre este mundo idealizado - onde certas atitudes são prescritas ou interditadas por uma integração de sistemas de normas que se querem coerentes (código cavaleiresco, valores cristãos) - e todo um mundo concreto dos comportamentos humanos, onde os seus coparticipantes devem fazer escolhas e negociações várias com direito às incoerências que aparecem livremente atualizadas na realidade vivida.

No plano geral da narrativa mais ampla, ocorre uma espacialização de algumas etapas. Cada acontecimento marcante é assinalado por um território explicitamente mencionado na narrativa. Coimbra corresponde ao equilíbrio; em Avelãs é realizado o rapto; para Leão ocorre a fuga que irá obstaculizar a justiça mediadora; e em Castel Rodrigo (lugar da 'intervenção') será restaurado o equilíbrio com a solução de todos os problemas. Estes signos espaciais assinalam a entrada de complicadores e descomplicadores do enredo, sinalizando a narrativa passo a passo. Além disto, tal como será possível verificar em outras narrativas, toda sentença definitiva que encerra um processo de mediação régia mostra-se normalmente associada a um espaço territorial muito bem explicitado, o que corresponde, adicionalmente, a um recurso retórico de convencimento.

Todas as questões até aqui discutidas são esclarecedoras, e lançam luz sobre os processos de recepção da narrativa e de sua eficácia como exempla. O tema paralelo mais importante, contudo, corresponde talvez ao vasto circuito de mediações que se estabelece a princípio entre dois reis, o de Portugal e o de Leão. Institui-se, com isto, o princípio de que a mediação régia está associada à figura do rei independentemente de seu país. O crime perpetrado em outro reino pode ser resolvido pelo rei vizinho, que pode então atuar como mediador independentemente do local de origem das pessoas envolvidas. Por um lado, esta ideia reforça a ideia do rei como 'sujeito’ da mediação. Por outro lado, o rei é impulsionado por uma força mais ampla que corresponde ao cumprimento da virtude cavaleiresca - é em função deste código que se cria uma linguagem e uma ética comum aos governantes de todos os reinos na sua atividade mediadora, o que permite, em tese, que um continue o 
trabalho iniciado pelo outro, e que o rei de Leão substitua o rei de Portugal se assim as circunstâncias o exigirem. Desta forma, o rei é simultaneamente 'sujeito' de um processo de mediação e 'instrumento' de um código cavaleiresco que deve guiá-lo.
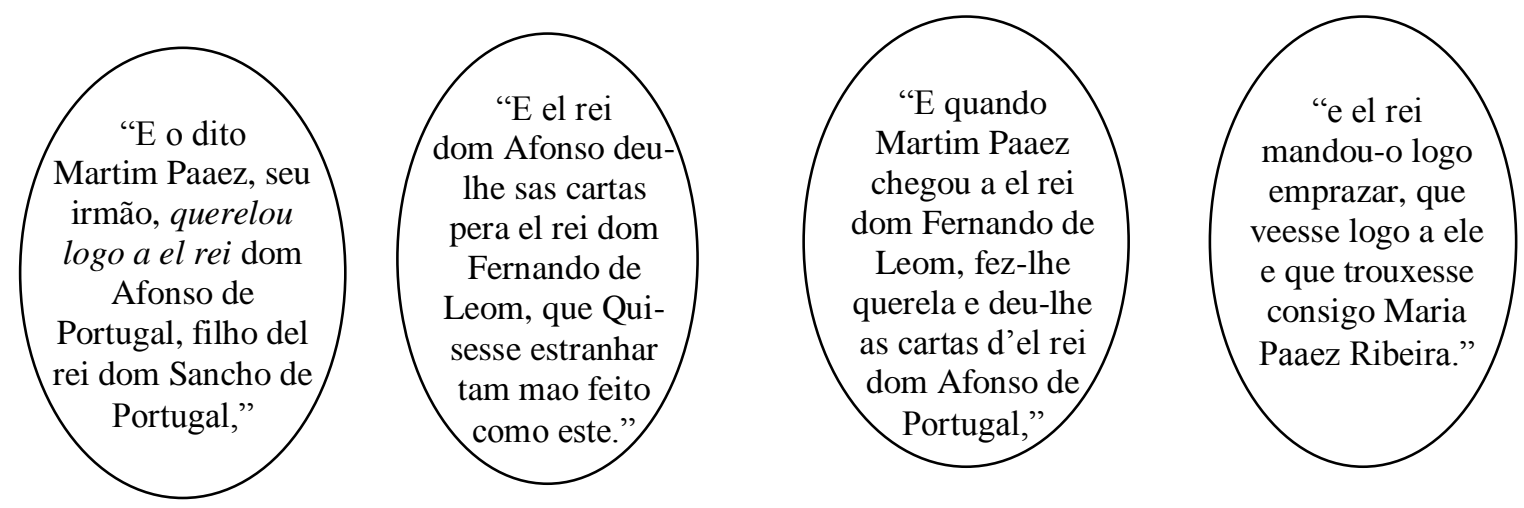

ação determinante do nobre

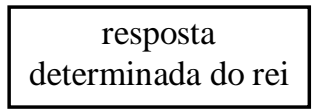

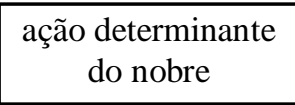

resposta determinada do rei

[Quadro 2: A mediação régia determinada pela nobreza: Decodificação do trecho entre as linhas 11-16, conforme padrão de determinação e resposta (grifos nossos)]

Outrossim, nas várias sequências integradas a esta sofisticada trama, pudemos perceber, mais uma vez, a figura do nobre que desempenha um papel capital em cada etapa seqüencial da 'intervenção' - esta que pode ser considerada o verdadeiro núcleo do processo de mediação. Vale lembrar que, neste caso, a integração do nobre ao aspecto 'intervenção' ocorreu de diversas maneiras - seja de forma positiva, através da pressão sobre o rei para que se realizasse o processo, seja de forma negativa, através de manipulações e ações sobre o raptor.

Desta forma, em um primeiro momento é o nobre Martim Paes, irmão da vítima, quem atua diretamente no processo de justiça - primeiro cobrando do rei de Portugal uma ação justiceira e intermediadora, depois levando ao rei de Leão as cartas que o primeiro governante régio lhe dera. É o próprio texto narrativo que explicita (linhas 11-16), de forma admirável, a alternância entre os 'fazeres' do nobre e as ações régias - meras respostas às solicitações do primeiro. 
Em um segundo momento, conforme pudemos decifrar sistematicamente, é a própria Maria Paes Ribeira quem intervém menos ou mais perceptivelmente por trás da mediação régia - tanto elaborando uma manipulação que evita que o nobre recalcitrante não compareça diante do rei, como implorando que este sentencie o infrator na mesma medida dos seus atos. É ela, mais do que o rei, quem rigorosamente condena o raptor (linhas 24-25). Afinal, caso ela se mostrasse uma vítima conformada e adaptada à nova situação, não teria o rei outro remédio senão o de legitimar o rapto. Mais uma vez, o processo mediador aparece não apenas partilhado entre realeza e nobreza, mas na verdade interferido determinantemente por ela.

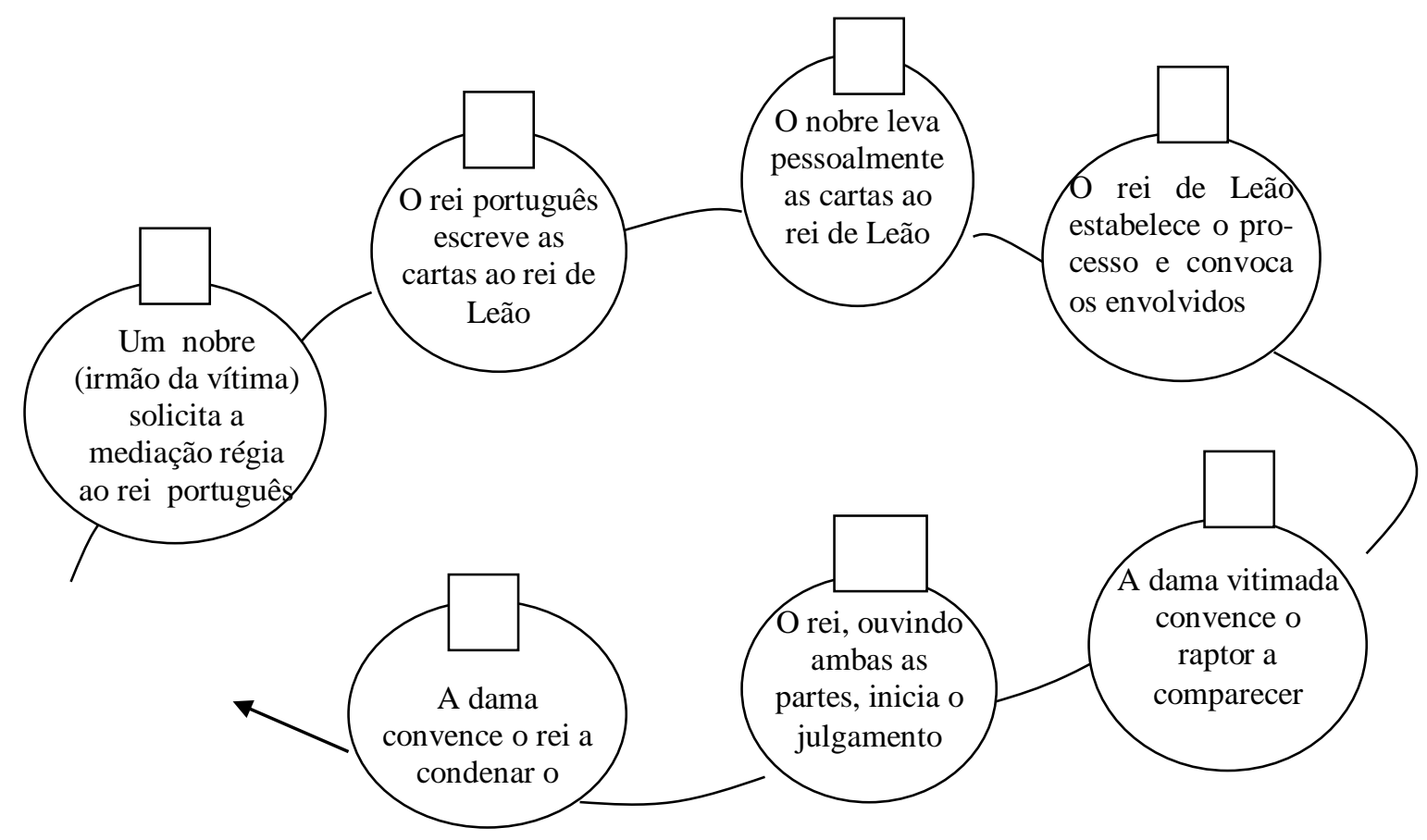

Quadro 3:

A 'rede de intervenções' na narrativa "A Ribeirinha"

As demais narrativas de mediação régia que aparecem no material linhagístico, e cujas análises não reproduziremos aqui para não carregar o texto com exemplos reincidentes, revelam sistematicamente o fundamento da intervenção nobiliárquica por trás da intervenção régia de superfície. Ao menos em alguns extratos de sentido, o nobre é o 
verdadeiro 'sujeito' por trás do 'sujeito'. A estrutura de intervenções múltiplas partilhadas entre nobreza e realeza encontra uma excepcional explicitação na narrativa que acabamos de analisar. Um esquema simplificado pode traduzir a sucessão de intervenções no que ela tem de essencial (Quadro 3).

A 'parte' de intervenção encaminhada pela nobreza $(\mathrm{N})$, como pudemos ver, parece vir sempre marcada por uma atuação determinante e positiva, onde a nobreza através da figura de um dos seus representantes assume o papel de um verdadeiro 'sujeito de fazer' A parte de intervenção régia (R), em contrafase, vem como que determinada pelo sujeito anterior, convertendo-se o rei em um 'sujeito secundário' (ou 'menos ativo') que é levado a agir através do objeto que instrumentaliza a mediação (as cartas, a convocação, a sentença de condenação). O rei, à parte sua euforização como figura de força e justiça, aparece desta forma instrumentalizado pela nobreza, que agora se mostra como o verdadeiro núcleo da autoridade mediadora.

De resto, seria dizer que a leitura nobiliárquico-linhagística da mediação régia - ao menos a leitura que se torna possível ao nível de profundidade dado a perceber pela estrutura implícita da narrativa - revela a ideia de uma 'mediação compósita'. A entender por aqui, o processo de mediação régia não diz apenas respeito ao rei, mas ainda com mais propriedade à nobreza ou a uma parcela da nobreza - que se vê representada no corpo de nobres que aconselham ou pressionam o governante mediador. $\mathrm{O}$ 'rei' como cabeça de um corpo político, poderíamos acrescentar, não se reduz nesta leitura à figura individualizada de um monarca singular, mas engloba uma "autoridade compósita" que se constitui da dualidade integralizada pelo rei propriamente dito e pelo seu corpo de 'bons nobres' aconselhadores. Com isto, a imagem da 'cabeça' - reduto simbólico da realeza - parece ser invadida por um setor da nobreza que lhe disputa a autoridade efetiva, o que testemunha um pouco desta complexa guerra de representações que se estabelece no interior da ideia da 'mediação régia'

A análise até aqui empreendida pode ser confirmada em inúmeras outras narrativas linhagísticas dos livros de linhagens portugueses dos séculos XIII e XIV. Tentaremos avançar nesta parte final para uma perspectiva mais ampla, mas ainda tomando a narrativa "O Rapto da Ribeirinha" e "O Tenreiro" como entradas para projetar algumas conclusões 
que seriam também válidas para um universo mais amplo de narrativas. Em vista disto, deverá ficar claro que a utilização de quadrados semióticos não só é eficaz para a análise de narrativas isoladas, como também para a abordagem de séries inteiras de narrativas.

Escolhemos, como pontos de partida, dois problemas similares que aparecem em cada uma das narrativas (mas que são fundamentalmente o mesmo problema de base). $\mathrm{O}$ primeiro refere-se à questão moral do 'sacrifício de um valor cavaleiresco menor em função de outro maior e mais importante' - ou, na contrapartida, à 'perpetração de um ato nãocavaleiresco moderadamente injusto para corrigir uma injustiça maior'. O segundo referese à perda de um valor cavaleiresco em vista de um engano provocado por uma situação ou por um personagem maldoso. Ambos os problemas nos falam de uma situação bastante recorrente na série de narrativas dos livros de linhagens - a passagem da 'afirmação cavaleiresca' para a 'transgressão cavaleiresca', e concomitantemente a necessidade do seu processo de retorno.

O primeiro problema escolhido se expressa na já estudada utilização da 'mentira' pela Ribeirinha para realizar seu justo plano de vingança e resgate da honra familiar. Vimos como a personagem havia se valido do engodo para persuadir o seu raptor a comparecer ao julgamento do rei - encobrindo com isto os seus verdadeiros sentimentos e oferecendo-se como falsa conciliadora, não faltando o recurso à 'tentação' mediante promessas concretas que finalmente seduziram o raptor. Tudo foi perfeitamente justificado como a única forma de restaurar a honra cavaleiresca, dentro do princípio de que os fins justificam os meios. Mas nada disto se passou sem algum constrangimento, registrado em alguns indícios narrativos que incorporam a 'culpa' e algumas passagens marcadas pela vergonha. O último parágrafo da narrativa resume o problema: "E ela disse que esto lhe nom dissera senom pera o trazer perante el rei, pera haver corregido o mal que lhe fizera, ca per outra guisa nom poderia del vingada seer"

Da mesma forma, não é possível compreender que o raptor tivesse sido enganado tão facilmente se a enganadora não tivesse desenvolvido, durante o período em que estivera sob o domínio do raptor, relações sexuais e ‘amorosas' próximas da normalidade com o seu pretenso candidato a marido. Estas questões estão implícitas na narrativa, e emergem se o 
leitor-ouvinte se põe a meditar sobre elas. O problema moral, ou o constrangimento moral, é colocado assim tanto nos planos do explícito como do implícito.

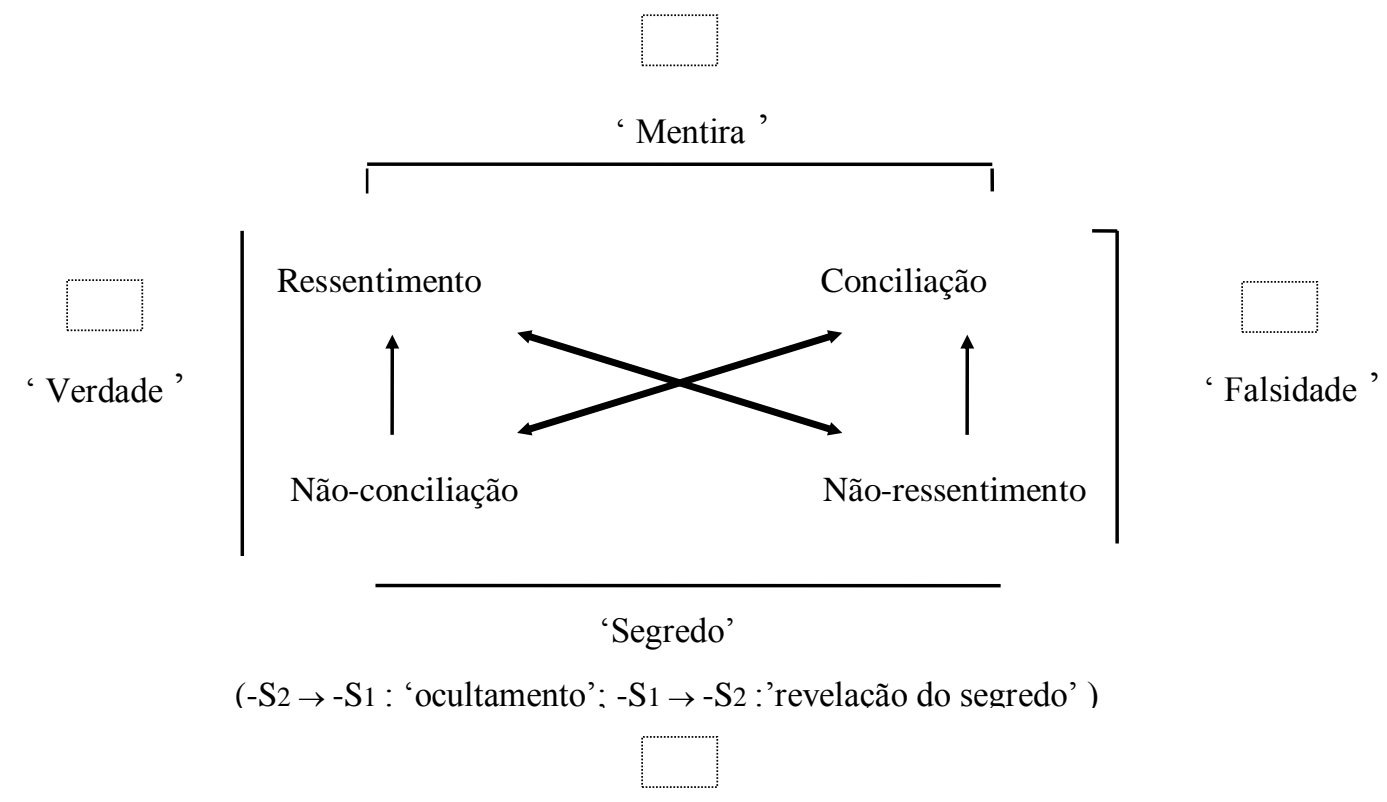

O 'grupo de Klein’ proposto mostrava para esta narrativa como não era possível se dirigir da 'verdade' à 'falsidade' sem passar pela 'mentira' ou pelo 'ocultamento' (caminho pelas beiradas), e como era preciso dissimular o 'ressentimento' em 'não-ressentimento' de modo a propor enganosamente uma 'conciliação' entre o raptor e a família da vítima (caminho pela diagonal positiva).

Para uma personagem comprometida com a honra e a ética cavaleiresca, não é possível vivenciar a 'mentira' (ou qualquer outra contravirtude cavaleiresca) sem certo 'constrangimento'. Tampouco é possível para o leitor-ouvinte cavaleiresco da Idade Média deixar de experimentar um 'constrangimento' equivalente ao vivenciar literariamente esta primeira passagem. No caso, o constrangimento é produzido pelo 'sacrifício consciente de um valor cavaleiresco', ao que teve de se submeter a personagem que sacrifica momentaneamente a 'verdade' em vista de outras finalidades mais prementes (a 'justa vingança' e a 'honra'). Do início ao fim da narrativa, somente a Ribeirinha tem o controle total do processo de dissimulação. O leitor que percebe isto no próprio decurso do tempo narrativo acompanha o constrangimento da personagem diante da 'mentira' que deve ser utilizada. O leitor que só o percebe no momento final (tal como o personagem-raptor), 
experimenta até o momento da revelação terminal o constrangimento de ver uma mulher honrada sujeitar-se resignadamente a um rapto injusto. O leitor que apenas desconfia do que se passa, por fim, experimenta ambos os constrangimentos e ainda a angústia de oscilar entre as leituras que se abrem para os dois finais possíveis da trama.

Enquanto realiza o trajeto da 'manipulação', dissimulando seus verdadeiros sentimentos por um duplo processo de 'ocultamento' e 'falseamento da realidade' que desemboca no metatermo ' $b$ ', a personagem encontra-se com a sua honra questionada, ou pelo menos suspensa. Quando ela inicia o processo de volta, em direção à 'verdade desvelada', a situação deixa de ser constrangedora para entrar no âmbito do 'esclarecimento'. Compreende-se agora como ‘justo' o sacrifício de um valor menor por outro mais importante (a 'mentira' pela 'reparação da honra') - e inicia-se um processo de 'remissão' da personagem (o que também se expressa por um alívio do leitor-ouvinte em relação a ele). Tudo conduz ao metatermo 'a' - quando, ao desvelar-se a 'verdade', o mal é corrigido e a honra da personagem é plenamente reafirmada. Façamos a superposição das expressões acima colocadas no quadrado semiótico já elaborado. 

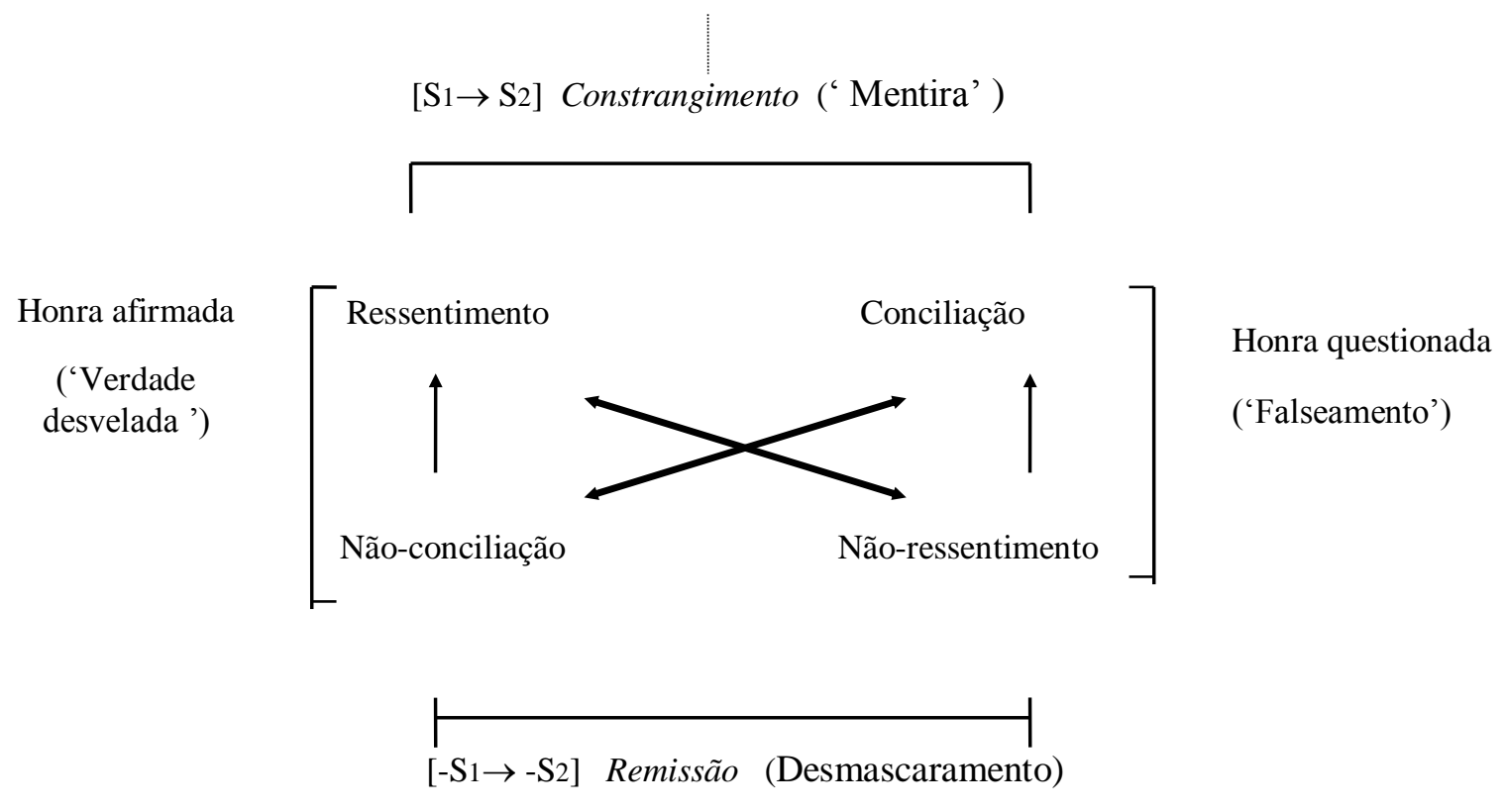

Afirmação cavaleiresca

Transgressão cavaleiresca

No quadro acima, o campo à direita também pode ser lido como o âmbito da 'transgressão cavaleiresca'; e o campo à esquerda como o âmbito da 'afirmação cavaleiresca'. Na verdade, como tantas outras interpolações dos livros de linhagens, a narrativa trata disto: da passagem da 'afirmação cavaleiresca' (onde a honra é afirmada, mantida ou reconquistada) para a 'transgressão cavaleiresca' (onde a honra é questionada, suspensa ou abalada). Esta passagem não se produz sem um inevitável 'constrangimento' para a figura do herói ou do nobre honrado. Da mesma forma, o retorno do âmbito da transgressão ou da desonra para a 'afirmação cavaleiresca' corresponde a um processo de 'remissão' do personagem, vivido naturalmente com certo alívio pelo 'esclarecimento da situação' que conduzirá à reafirmação da honra (note que, para maior eficácia da análise, os metatermos ' 1 ' e 'ab' aparecem agora orientados, permitindo uma única direção que simplifica a questão).

Na narrativa "A Ribeirinha", a personagem central realiza este circuito completo. Seria possível examinar também a figura do bom nobre, o irmão da vítima, que permanece 
rigorosamente no campo da afirmação cavaleiresca (coerentemente circulando apenas entre o ressentimento e a não-conciliação) - mas constituindo-se efetivamente em um parceiro da vítima (para fins narrativos) no processo de 'intervenção'. Ele desconhece a atuação manipuladora da Ribeirinha, mas faz a sua parte exigindo do rei o cumprimento da justiça sem o que, o processo sequer se instalaria e o plano dissimulador da personagem central não teria sentido. Tal como o irmão da vítima e a própria vítima, os diversos tipos atuantes na narrativa se distribuem em relação ao quadrado proposto: o mundo cavaleiresco dos bons nobres e do rei, e o mundo não-cavaleiresco do raptor.

Este momento é oportuno para um desvio que deverá suprir uma questão que havia ficado pendente: a das tensões existentes entre a realidade literária idealizada dos livros de linhagens e a realidade extraliterária plena de incoerências e contradições que constitui o concreto vivido. O episódio narrado em "O Rapto da Ribeirinha" correspondeu seguramente a uma motivação concreta. Não se trata aqui de uma narrativa de fundo mítico ou de uma reconstrução radical de memória a partir de algum episódio histórico importante. A narrativa refere-se a um rapto efetivamente ocorrido, e teria partido, portanto, de acontecimentos que um dia teriam sido vividos.

O mundo da realidade extraliterária é este mundo onde os comportamentos sociais efetivamente se estabelecem na vida cotidiana, em uma rede de interações complexas que colocam os vários atores sociais uns em confronto com os outros, e todos sujeitos a circunstâncias e contextos vários que lhes permitem tomar decisões, realizar escolhas, negociações, manipulações diversificadas. O mundo vivido permite, sobretudo, que os homens mudem constantemente, que sejam até mesmo incoerentes e que expressem contradições múltiplas nos seus próprios atos. Ninguém vive, na realidade extraliterária, o código cavalheiresco da maneira como ele é imposto na mensagem de superfície da literatura. Tratamos aqui de um sistema normativo carregado por prescrições e interdições, não isento de contradições, dentro do qual os indivíduos concretos se movimentam com alguma liberdade, negociando a cada momento a sua atuação dentro deste sistema e também a possibilidade de continuarem inseridos nele, mas atualizando ao mesmo tempo todas as concessões necessárias para o encaminhamento de suas próprias vidas diante do que lhes é oferecido pela realidade cotidiana. 
Partimos não apenas de um rapto efetivamente ocorrido, é oportuno acrescentar, mas que parece ter se estabilizado durante um período significativo que não é informado na narrativa estudada (no tempo narrativo do nobiliário este período aparece dissolvido naquele espaço de tempo situado entre o rapto e o seu julgamento). Nada indica que, uma vez realizado o rapto ( situação não tão incomum na Idade Média), e colocada diante de uma nova situação, a Maria Paes Ribeiro da realidade vivida não tenha buscado adaptações ou negociações que a permitissem viver dentro da nova configuração para a qual a sua vida era transplantada.

Tal como fizemos notar, os pormenores e indícios deste jogo de adaptações e negociações aparecem referidos ou implicitados na própria narrativa (não seria possível negociar ou convencer o raptor sem com ele conservar boas relações, inclusive amorosas). A imaginação narrativa resolve esta contradição criando a ideia do plano premeditado, já descrito pormenorizadamente, no qual a vítima engana o raptor e o leva à condenação diante do rei. Mas ocorre que o tal plano, que só pode ter existido na imaginação literária, não poderia se realizar a não ser que a vítima tivesse informações permanentemente atualizadas com relação aos passos que concomitantemente iam sendo dados pelo irmão, no sentido de viabilizar a convocação do raptor e a realização do julgamento pelo rei. Esta sincronia, naturalmente, é literária (não faz parte do vivido). Caso as negociações do irmão não fossem bem sucedidas, o 'plano' da vítima não se realizaria e o seu ressentimento desejoso de se transformar em vingança permaneceria como um projeto mudo e inócuo.

Talvez a Maria Paes Ribeira da realidade vivida tenha se adaptado à nova situação do rapto estabilizado, podemos conjeturar isto. Quando ocorre a convocação, por esforço particular do irmão, ela vê-se confrontada com uma nova configuração: deve escolher entre a relação pseudoconjugal com o raptor, que já ia mostrando sinais de acomodação que repercutem na familiaridade com que ela o trata (indícios presentes na narrativa), e a relação familiar mais antiga, representada por sua inserção em uma cadeia linhagística que através do irmão pretende reparar sua honra. Agora é novamente preciso escolher, e a dama tende ao segundo bloco - o que, em todo o caso, é decorrência de sua escolha, uma vez que não são incomuns as situações em que a vítima acaba aceitando o raptor como esposo. 
Gomes Lourenço, aliás, jamais compareceria ao chamamento régio se não acreditasse enfaticamente nesta última possibilidade (que talvez tenha inclusive motivado as suas ações iniciais como raptor). Dentro de um "universo dos possíveis" que inclui o acordo com a família da vítima, não é de se estranhar que o raptor veja-se tentado a aceitar o que para ele vai se desenhando como uma proposta de negociação com os representantes da linhagem ultrajada. É possível mesmo que o rapto tenha sido para ele, desde o início, um investimento social - mais do que uma afronta ou um arroubo viril. Um investimento que comporta a sua dimensão de risco. E é este risco que ele finalmente assume enfrentar ao atender ao chamamento régio.

Da mesma forma, ao escolher a via da 'intermediação régia' em detrimento da via da 'vingança familiar', o irmão da vítima (e ao seu reboque a linhagem que ele representa) aceitam implicitamente a possibilidade de aceitar eventuais negociações (caso a vítima se ache conformada, caso os argumentos simbólicos e materiais do raptor sejam convincentes e venham adequadamente disfarçados em arrependimento, caso o rei tenda mais favoravelmente à estabilização do rapto, e assim por diante). Aqui se anuncia, portanto, um universo combinatório de escolhas, de manipulações, de decisões que contradizem outras antes tomadas, de incoerências assumidas pelos diversos atores sociais - um universo de liberdades, enfim, onde os indivíduos exercem a sua autonomia dentro de um quadro integrado de sistemas normativos que abrem generosamente as suas contradições para a livre exploração dos homens que os trazem à vida.

Os comportamentos individuais motivadores do episódio analisado, desta maneira, expressam em última instância a maneira de cada um utilizar a margem de manobra de que dispõe na situação imposta. A incerteza faz parte do jogo de relações sociais que se estabelece entre estes indivíduos que dispõem de certa "gama de possíveis", e esta incerteza mesmo é um elemento da trama tecida pelo "vivido". Nós mesmos, através do acesso oferecido pelas narrativas linhagísticas e cantigas trovadorescas, só podemos perceber destes indivíduos concretos - imprevisíveis coparticipantes de um jogo que tem em todo o caso as suas regras - os momentos em que eles devem efetuar uma escolha, tomar uma decisão, negociar a sua permanência em um grupo. 
Por sinal, é precisamente de negociar a sua permanência no grupo linhagístico de origem que trata a dama raptada. Enquanto isto, o raptor Gomes Lourenço negocia a sua entrada no novo circuito familiar e a legitimação do casamento que obteve à força. O irmão, representante da cadeia linhagística ultrajada, negocia de sua parte a reparação da honra familiar. E o rei, 'mediador de conflitos', negocia o reconhecimento simbólico de sua capacidade de mediação e de sua qualidade de justiça. Distribuídos os jogadores no tabuleiro social, com cada peça senhora de um de um lance que pode ser modificado à última hora, o jogo reafirma suas regras ao mesmo tempo em que o seu resultado final continua a mostrar-se imprevisível. Das incertezas e hesitações também tira este jogo o essencial de seu dinamismo.

Mas eis-nos de volta ao mundo da realidade literária dos nobiliários, onde deve ser concretizado o ideal cavaleiresco. O discurso linhagístico, que habitualmente reabsorve episódios vividos para convertê-los em exempla e para difundir um sistema normativo idealizado, empreende precisamente em um dos seus extratos de sentido uma espécie de 'limpeza' destas hesitações, contradições, negociações - pequenas impurezas quando examinadas da perspectiva cavaleiresca mais idealizada. As impurezas, as contradições, as mudanças de curso e retomadas de decisão, esta miríade de pequenos atos nãocavaleirescos que constituem a trama da própria vida são como que empurradas para o mundo dos pormenores, onde permanecem como indícios a serem decifrados pelos historiadores. Feita esta grande ressalva sempre necessária, voltaremos a seguir à identificação do padrão que está por trás desta 'limpeza cavaleiresca', esta que converte os mais variados episódios vividos em pequenas lições sobre a 'correta maneira de agir'. O padrão proposto estabelece como um dos sentidos estruturais deste tipo de narrativas a rede de valoração dos aspectos cavaleirescos.

O quadrado semiótico abaixo foi adaptado para abarcar situações expostas em várias das narrativas que aparecem nos livros de linhagens, e que não poderão ser analisadas neste breve artigo. Poder-se-ia, naturalmente, chegar a esquema que possa instrumentalizar um número mais amplo de narrativas, servindo para a análise de uma série inteira. (Importante: a palavra 'justo' pode ser substituída por 'corajoso', 'honrado', 'fiel', ou qualquer outro valor pertinente ao sistema cavaleiresco, conforme a narrativa que esteja 
sendo analisada). O percurso da transgressão - permanecendo ou tendendo ao lado direito do quadro ('a $\rightarrow 1 \rightarrow$ b' pela beirada superior; ' $\mathrm{S} 1 \rightarrow-\mathrm{S}_{1} \rightarrow \mathrm{S} 2$ ' pela diagonal positiva, etc...) -

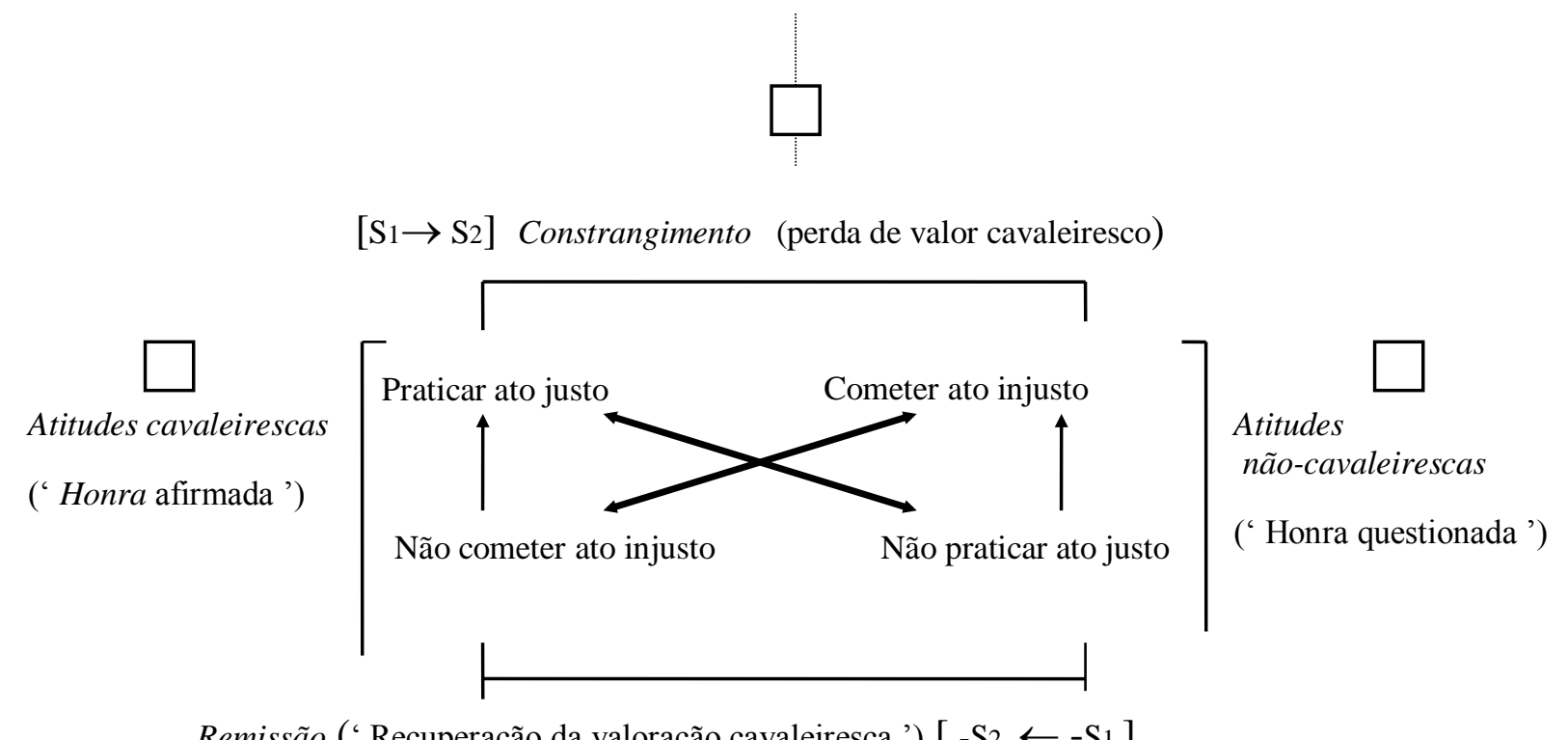

Remissão ('Recuperação da valoração cavaleiresca ') $[-\mathrm{S} 2 \leftarrow-\mathrm{S} 1]$

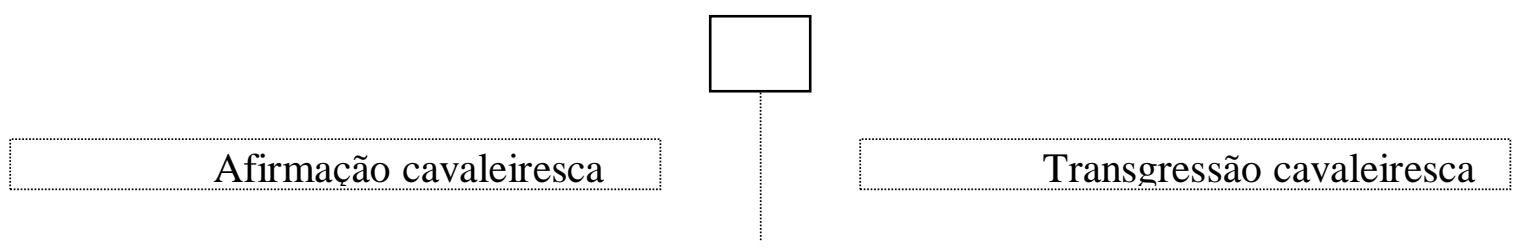

é 'disforizado', isto é, sofre uma depreciação afetiva ou um 'investimento tímico negativo', para utilizar a própria terminologia semiótica. O percurso da afirmação cavaleiresca, permanecendo ou tendendo ao lado esquerdo do quadro, é de modo inverso 'euforizado'.

Devemos observar que o quadrado permite organizar uma tipologia social de personagens conforme a sua posição ou trajetória em relação ao ideário cavaleiresco. O nobre ideal é aquele que, não apenas 'não comete atos injustos' (ou não-cavaleirescos de uma maneira geral) como também 'pratica atos de justiça'. Os piores 'maus nobres' são aqueles que, não satisfeitos em 'não praticar atos justos', conforme manda o código cavaleiresco, 'cometem atos injustos'. Aparecem ainda nos livros de linhagens, geralmente como coadjuvantes, os nobres que se resignam a não praticar atos injustos, sem praticarem em todo o caso atos justos (entenda-se no lugar de 'justo’ quaisquer outras virtudes)'. Os 
‘bons nobres' são euforizados, os 'maus nobres' são disforizados, e os 'nobres neutros' são 'aforizados' (não recebem qualquer investimento tímico, seja positivo ou negativo).

Diversos personagens das narrativas linhagísticas são ambíguos, inclusive alguns dos nobres que se movem de um campo a outro misturando valores e contravalores cavaleirescos (alguns se tornam meros veículos de enunciados organizáveis em ambos os campos do quadrado semiótico proposto). Mas os mais interessantes para os exempla linhagísticos são os nobres que - em sua trajetória ao longo da sucessão dos eventos atravessam um campo e outro movidos por forças maiores, ou em virtude de uma fatalidade ou plano mais amplo, ou ainda enganados pelas circunstâncias ou pelos homens. Os mais interessantes de todos para os propósitos linhagísticos são os que atravessam sistematicamente o quadrado de um ponto ao outro sem perderem fundamentalmente a sua essência.

Para o conjunto de narrativas que constituem o nosso corpus documental, algumas situações de 'trajetórias' são possíveis. Quando o personagem é um 'bom nobre', a transgressão cavaleiresca ou se dá no plano das aparências (processo de ocultamento para alcançar um fim maior), ou no plano da inconsciência (o nobre não toma consciência de que pratica um ato não-cavaleiresco). A passagem do mundo da honra para o mundo da desonra sempre envolve uma situação de constrangimento, mas entrevemos nela duas possibilidades conforme as situações supracitadas. No primeiro caso a passagem se faz mediante um 'sacrifício consciente de um valor cavaleiresco'. Se o nobre conserva a sua essência de 'bom nobre' até o final da narrativa (porque há os que interrompem o ciclo pela metade e se estabilizam no campo não-cavaleiresco), é porque a sua estadia no mundo dos contravalores cavaleirescos fora calculada ou visava a uma finalidade maior, sendo o trajeto de volta obrigatório. Em alguns casos, o retorno já estava previsto desde o princípio pelo bom nobre, que assume o papel de 'enganador' ou outro similar. A narrativa 'O Rapto da Ribeirinha" enquadra-se neste tipo. O trajeto de volta, nestas situações, sempre envolve um 'esclarecimento' - que leve o leitor ou os demais personagens a compreender, por exemplo, a justeza ou a necessidade de tolerar o sacrifício de um valor por outro maior. Ainda nestes casos, o nobre deve ser redimido não propriamente para si mesmo, mas para o leitor ou para 
os demais personagens envolvidos na trama. Este tipo de narrativa é valioso para compreender as hierarquizações de valores propostos pelos livros de linhagens.

No segundo caso o bom nobre não toma consciência, a princípio, da injustiça ou dos aspectos não-cavaleirescos dos seus atos. Tal como dissemos, o que permite a este bom nobre passar para o mundo da transgressão cavaleiresca sem perder a sua boa essência é a sua inconsciência. Assim que toma consciência de sua injustiça ou iniquidade, o bom nobre começa a empreender o caminho de volta. A remissão fundamenta-se no esclarecimento da ignorância ou da inconsciência da injustiça envolvida no ato antes praticado. Com frequência, o processo inicial de inconsciência é movido pelo engano infligido pelas circunstâncias ou por um opositor mal intencionado.

Uma variante alternativa entre as trajetórias 'consciente' e 'inconsciente' do bom nobre para o âmbito não-cavaleiresco é o trajeto da 'fatalidade', onde o bom nobre é arrastado pelas forças do destino para o circuito da transgressão, ou mesmo pela ação maldosa ou descuidada de um segundo personagem. Tomando consciência de sua transgressão, a qual não dependeu rigorosamente dele mesmo, o bom nobre luta desesperadamente para normalizar a sua situação, e não descansa enquanto não conseguir realizar efetivamente o trajeto de volta.

Vimos até aqui os modelos narrativos de transgressão e valoração cavaleiresca a partir da figura do 'bom nobre', e seria possível examinar também os modelos narrativos que se constroem em torno da figura do 'mau nobre'. Devido aos limites na extensão deste artigo, contudo, finalizaremos apontando este caminho apenas como uma perspectiva que se abre como continuidade para a análise desenvolvida até aqui. Os resultados a que chegamos - a partir do rastreamento dos modelos presentes nas narrativas linhagísticas e da utilização de quadrados semióticos - vêm a mostrar que, por de trás do código cavaleiresco aí proposto, há um sistema ético envolvido. Há algo que se coloca como ‘justo’ na sua relação com o 'não-justo' e com o 'injusto', e elementos que medeiam esta relação (a qualidade do ato como 'voluntário' e 'consciente', a necessidade de retribuir a justiça ou a injustiça com um ato que instaure ou restabeleça a 'reciprocidade', a 'hierarquização' de tipo geométrico entre 'males menores' e 'mal maior', e assim por diante). 


\section{REFERÊNCIAS BIBLIOGRÁFICAS}

\section{FONTES}

Livro de Linhagens do Conde D. Pedro. ed. José Mattoso. "Nova Série" dos Portugaliae Monumenta Historica. Lisboa: A.C.L., 1980.

Livros Velhos de Linhagens. (incluindo o "Livro Velho" e o "Livro do Deão"). ed. José Mattoso e Joseph Piel. "Nova Série" 2 Portugaliae Monumenta Historica. Lisboa: Academia de Ciências, 1980.

\section{BIBLIOGRAFIA CITADA}

BREMOND, Claude. Logique du récit. Paris: Seuil, 1973).

CARDOSO, Ciro Flamarion. Narrativa, Sentido, História. Campinas: Papirus, 1997.

GREIMAS, Algirdas Julien e COURTÉS, Joseph. Dicionário de Semiótica. S. Paulo: Cultrix: 1989

TODOROV, Tzvetan. Littérature et signification. Paris: Laroussse, 1967. 